\title{
Gambaran Infeksi Acinetobacter baumannii dan Pola Sensitifitasnya terhadap Antibiotik
}

\author{
I Wayan Gustawan, ${ }^{*}$ Hindra Irawan Satari, ${ }^{*}$ Idham Amir, ${ }^{*}$ Dalima AW Astrawinata ${ }^{* *}$ \\ "Departemen Ilmu Kesehatan Anak, "Departemen Patologi Klinik Fakultas Kedokteran Universitas \\ Indonesia/RSUPN Dr Cipto Mangunkusumo, Jakarta
}

Latar belakang. Adanya peningkatan insiden infeksi Acinetobacter baumannii yang disertai peningkatan kejadian resistensi antibiotik, peningkatan morbiditas dan mortalitas, dan terbatasnya laporan kejadian infeksi bakteri ini pada pasien anak.

Tujuan. Mengetahui gambaran infeksi Acinetobacter baumannii dan pola sensitifitasnya terhadap antibiotik di Departemen Ilmu Kesehatan Anak RSUPN Dr Cipto Mangunkusumo.

Metode. Merupakan penelitian deskriptif retrosfektif melalui penelusuran data hasil biakan darah di laboratorium dan rekam medis dari Januari-Desember 2012.

Hasil. Didapatkan 47 isolat darah Acinetobacter baumannii dari 32 pasien. Penelusuran rekam medis mendapatkan 24 data pasien lengkap. Semuanya merupakan pasien ruang NICU, sebagian besar laki-laki (18/24) dan neonatus kurang bulan (18/24). Gambaran klinis menunjukkan rerata frekuensi denyut jantung $148 \mathrm{kali} /$ menit, frekuensi napas $55 \mathrm{kali} / \mathrm{menit}$, suhu aksila $37,1^{\circ} \mathrm{C}$, kadar leukosit $12767,8 / \mathrm{mm}^{3}$, kadar trombosit 58491,3/ $\mathrm{mm}^{3}$, kadar procalcitonin $17,6 \mathrm{ng} / \mathrm{mL}$, dan CRP 88,5 mg/L. Rerata lama perawatan sebelum terjadi infeksi 23,9 hari. Sebagian besar pasien menggunakan alat medis seperti ventilator, CPAP, jalur vena sentral, jalur vena perifir, dan pipa nasogastrik dengan rerata lama pemakaian masing-masing $17,9,4,5,20,9,13,3$, dan 17,3 hari. Semua pasien mendapat antibiotik sebelum infeksi dengan rerata lama pemberian 22,5 hari. Uji kepekaan antibiotik mendapatkan 23 isolat (23/24) merupakan MDR. Resistensi antibiotik didapatkan pada golongan aminoglikosida, carbapenem, quinolon, sefalosporin, penisilin-beta lactamase inhibitor, dan tigesiklin. Sebagian besar penderita meninggal dalam perawatan (18/24).

Kesimpulan. Semua pasien yang menderita infeksi Acinetobacter baumannii dirawat di ruang NICU, sebagian besar pasien merupakan kasus MDR. Sari Pediatri 2014;16(1):35-40.

Kata kunci: infeksi Acinetobacter baumannii, pola resistensi, antibiotik

Alamat korespondensi:

Dr. I Wayan Gustawan, MSc., SpA. Departemen Ilmu Kesehatan Anak Fakultas Kedokteran Universitas Indonesia/RSUPN Dr Cipto Mangunkusumo, Jalan Salemba 71 Jakarta Pusat. E-mail: iwayangustawan@gmail.com

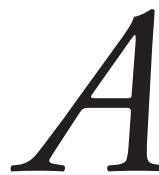

cinetobacter baumannii merupakan kuman patogen yang menjadi masalah utama pada kasus-kasus infeksi yang didapat di rumah sakit. Secara global, dilaporkan insiden infeksi di rumah sakit yang disebabkan oleh Acinetobacter 
baumannii meningkat secara signifikan terutama pada pasien yang dirawat di ruang rawat intensif. ${ }^{1-3}$ Laporan penelitian tentang infeksi Acinetobacter baumannii ini sebagian besar merupakan pasien dewasa, sedangkan pasien anak masih sedikit yang dilaporkan. Hosoglu $\mathrm{dkk}^{4}$ melaporkan kejadian luar biasa di ruang NICU (Neonatal Intensive Care Unit) Diyarbakir Children's Hospital's (Turki) selama bulan November 2006 sampai Agustus 2007, terdapat 64 bayi menderita sepsis karena Acinetobacter baumannii. Kanokorn dkk ${ }^{5}$ meneliti kejadian infeksi Acinetobacter baumannii pada pasien anak didapatkan insiden infeksi dan kolonisasi Acinetobacter baumannii 1,4\%. Suatu studi kohort retrospektif di salah satu rumah sakit Saudi Arabia selama 6 tahun dilaporkan terdapat kecenderungan peningkatan jumlah pasien anak dengan infeksi Acinetobacter baumannii. ${ }^{6}$

Peningkatan insiden infeksi oleh Acinetobacter baumannii pada pasien rumah sakit ternyata juga diikuti oleh peningkatan kejadian resistensi terhadap berbagai antibiotik. ${ }^{2}$ Pada tahun 1992, dilaporkan mulai ada wabah Acinetobacter baumannii yang resisten terhadap beberapa jenis antibiotik di rumah sakit Barcelona, Spanyol. Acinetobacter baumannii yang resisten terhadap golongan carbapenem ditemukan tahun 1997.7 Di negara-negara Asia dan Timur Tengah, kejadian infeksi Acinetobacter baumannii yang multiresisten juga telah dilaporkan. ${ }^{2,8}$ Hong $\mathrm{dkk}^{8}$ melaporkan kejadian luar biasa infeksi Acinetobacter baumannii yang resisten terhadap imipenem. Penggunaan kateter intravena, adanya kolonisasi sebelumnya, adanya kegagalan sistem respirasi dan kardiovaskular, perawatan lama di rumah sakit, perawatan di ruang rawat intensif, penggunaan ventilator, prosedur invasif dan terpapar oleh antibiotik yang lama akan meningkatkan risiko mengalami infeksi Acinetobacter baumannii. ${ }^{1,3}$ Acinetobacter baumannii bakterimia menyebabkan penambahan lama pemakaian ventilator dan lama rawat di ruang rawat intensif dibandingkan dengan pasien lain tanpa bakterimia karena Acinetobacter baumannii.' Infeksi Acinetobacter baumannii berkaitan dengan peningkatan morbiditas dan peningkatan lama rawat di rumah sakit. Infeksi Acinetobacter baumannii yang multiresisten berhubungan dengan peningkatan angka kematian pasien kritis yang dirawat di ruang rawat intensif. ${ }^{1}$

Adanya peningkatan insiden infeksi Acinetobacter baumannii yang disertai peningkatan kejadian resistensi terhadap antibiotik, peningkatan morbiditas dan mortalitas akibat infeksi bakteri ini, serta terbatasnya laporan kejadian infeksi Acinetobacter baumannii pada pasien anak, mendorong dilakukan penelitian ini untuk mengetahui bagaimana gambaran infeksi Acinetobacter baumannii di ruang rawat anak dan pola sensitifitas kuman terhadap antibiotik.

\section{Metode}

Penelitian deskriptif retrospektif untuk mencari kejadian infeksi Acinetobacter baumannii dan pola resistensinya terhadap antibiotik. Subyek penelitian adalah semua anak yang dirawat di ruang rawat pediatri RSUPN dr Cipto Mangunkusumo dari Januari-Desember 2012 yang menderita infeksi Acinetobacter baumannii.

Penelitian dilakukan dengan mengambil data dari pasien yang dirawat di ruang rawat anak yang hasil biakan darahnya positif Acinetobacter baumannii. Untuk mengetahui pasien yang hasil biakan darahnya positif, dilakukan penelusuran melalui data isolat di laboratorium Patologi Klinik RSUPN dr Cipto Mangunkusumo dilanjutkan dengan penelusuran rekam medis pasien. Apabila data tidak lengkap maka dikeluarkan dari penelitian. Definisi multidrug resistant (MDR) yang digunakan sesuai dengan definisi International Expert Proposal for Interim Standard Definitions for Aquired Resistance yaitu apabila dijumpai adanya isolat yang resisten terhadap minimal 1 antibiotik dari $\geq 3$ golongan antibiotik. ${ }^{10}$

\section{Hasil}

Di antara 2729 isolat pasien ruang anak (ruang NICU, PICU, bangsal perawatan lantai 1 gedung A dan bangsal perawatan bedah anak), didapatkan 47 isolat darah mengandung Acinetobacter baumannii dari 32 pasien. Penelusuran rekam medis pasien di ruang NICU, 24 data pasien lengkap, terdiri dari 18 (18/24) laki-laki dan 6 (6/24) perempuan serta sebagian besar merupakan neonatus kurang bulan (18/24) (Tabel 1). Gambaran klinis didapatkan rerata frekuensi denyut jantung $148 \mathrm{kali} /$ menit, frekuensi napas $55 \mathrm{kali} / \mathrm{menit}$, suhu aksila $37,1^{\circ} \mathrm{C}$, kadar leukosit $12767,8 / \mathrm{mm}^{3}$, trombosit $58491,3 / \mathrm{mm}^{3}$, procalcitonin $17,6 \mathrm{ng} / \mathrm{ml}$, dan CRP 88,5 mg/L. Rerata lama perawatan sebelum terjadinya infeksi adalah 23,9 hari. Sebagian besar pasien meninggal dalam perawatan (18/24) dengan rerata lama perawatan 49,3 hari. 
Tabel 1. Karateristik subyek penelitian

\begin{tabular}{lc}
\hline Karakteristik & $\mathrm{n}$ \\
\hline Jenis kelamin & 18 \\
Laki-laki & 6 \\
Perempuan & \\
Penyakit dasar & 18 \\
NKB & 1 \\
Kembar siam & 1 \\
Hidrosefalus & 1 \\
Ekstropia bulbi & 2 \\
Kelainan gastrointestinal & 1 \\
Kelainan jantung & 1 \\
BIHA & 148 \\
Pemeriksaan tanda vital (rerata) & 55 \\
Frekuensi denyut jantung (kali/menit) & 37,1 \\
Frekuensi napas (kali/menit) & \\
Suhu aksila $\left({ }^{\circ} \mathrm{C}\right)$ & 12767,8 \\
Pemeriksaan laboratorium (rerata) & 58491,3 \\
Leukosit (/mm $\left.{ }^{3}\right)$ & 17,6 \\
Trombosit (/mm ${ }^{3}$ ) & 88,5 \\
Procalcitonin $(n g / m l)$ & 23,9 \\
CRP (mg/L) & 49,3 \\
Lama rawat sebelum infeksi (rerata, hari) & \\
Lama rawat total (rerata, hari) & 6 \\
Keluaran & 18 \\
Sembuh & Meninggal
\end{tabular}

$\mathrm{NKB}=$ neonatus kurang bulan, $\mathrm{BIHA}=$ bayi dari ibu penderita HIV/AIDS, $\mathrm{NICU}=$ neonatal intensive care unit, $\mathrm{CRP}=$ C-reactive protein
Tabel 2. Beberapa faktor risiko infeksi Acinetobacter baumannii

\begin{tabular}{lcc}
\hline Faktor risiko & $\mathrm{n}$ & $\begin{array}{c}\text { Rerata lama pemakaian } \\
\text { (hari) }\end{array}$ \\
\hline Pemakaian alat & 17 & 17,9 \\
Ventilator & 12 & 4,5 \\
CPAP & 13 & 20,9 \\
Vena sentral & 23 & 13,3 \\
Vena perifir & 0 & 0 \\
Kateter urin & 18 & 17,3 \\
Pipa nasogastrik & 24 & 22,5 \\
Pemberian antibiotik &
\end{tabular}

$\mathrm{CPAP}=$ continues positive airway pressure

Didapatkan sebagian besar pasien menggunakan alat seperti ventilator, CPAP, jalur vena sentral, jalur vena perifir dan pipa nasogastrik dengan rerata lama pemakaian masing-masing 17,9, 4,5, 20,9, 13,3, dan 17,3 hari (Tabel 2). Semua pasien mendapatkan antibiotik sebelum infeksi Acinetobacter baumannii dengan rerata lama pemberian 22,5 hari.

Dari uji kepekaan antibiotik didapatkan sebagian besar (23/24) Acinetobacter baumannii merupakan multidrug resistant (MDR). Sebagian besar isolat

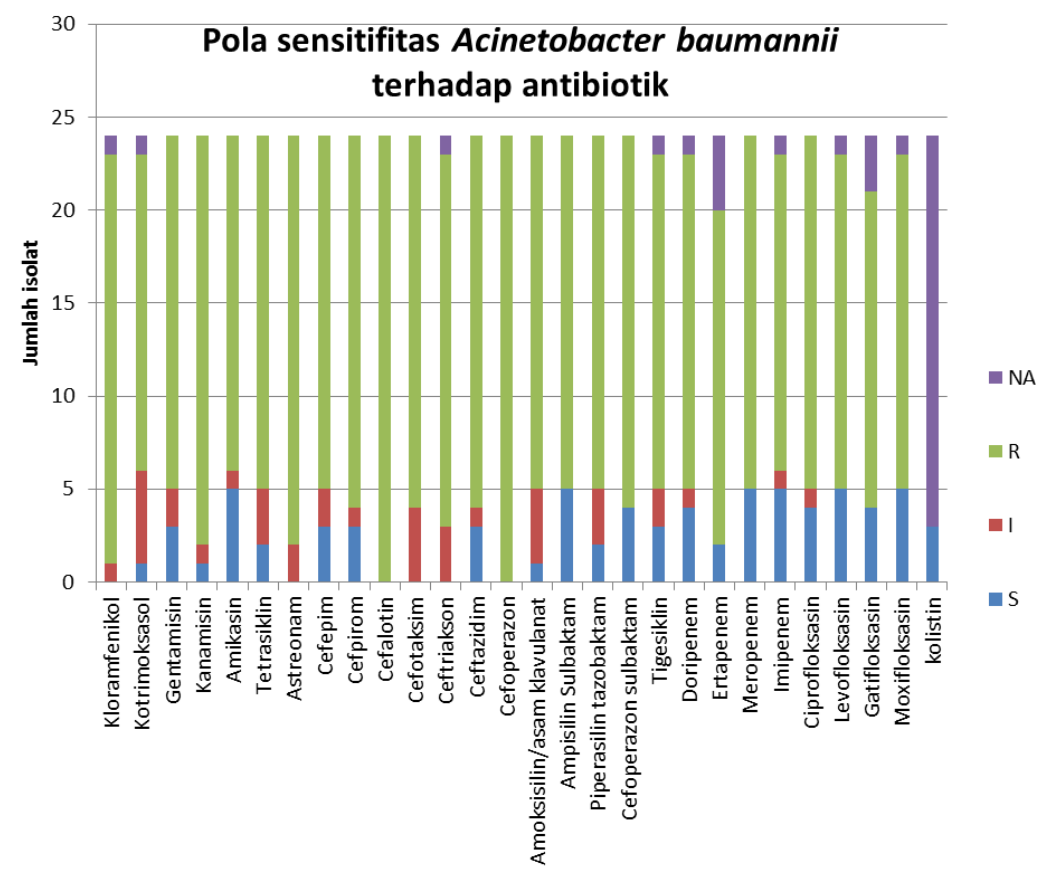

$\mathrm{R}=$ resisten; I=intermediet; $\mathrm{S}=$ sensitif; $\mathrm{NA}=$ not available

Gambar 1. Pola sensitifitas Acinetobacter baumanii terhadap antibiotik 
I Wayan Gustawan dkk: Gambaran infeksi Acinetobacter baumannii dan pola sensitifitasnya terhadap antibiotik

Tabel 3. Pola sensitifitas Acinetobacter baumanii terhadap masing-masing antibiotik ( $\mathrm{n}=24)$

\begin{tabular}{|c|c|c|c|c|}
\hline Antibiotik & S & I & $\mathrm{R}$ & NA \\
\hline Kloramfenikol & 0 & 1 & 22 & 1 \\
\hline Kotrimoksasol & 1 & 5 & 17 & 1 \\
\hline \multicolumn{5}{|l|}{ Golongan aminoglikosida } \\
\hline Gentamisin & 3 & 2 & 19 & 0 \\
\hline Kanamisin & 1 & 1 & 22 & 0 \\
\hline Amikasin & 5 & 1 & 18 & 0 \\
\hline Tetrasiklin & 2 & 3 & 19 & 0 \\
\hline Astreonam & 0 & 2 & 22 & 0 \\
\hline \multicolumn{5}{|l|}{ Golongan sefalosporin } \\
\hline Cefepim & 3 & 2 & 19 & 0 \\
\hline Cefpirom & 3 & 1 & 20 & 0 \\
\hline Cephalotin & 0 & 0 & 24 & 0 \\
\hline Cefotaksim & 0 & 4 & 20 & 0 \\
\hline Ceftriakson & 0 & 3 & 20 & 1 \\
\hline Ceftazidim & 3 & 1 & 20 & 0 \\
\hline Cefoperazon & 0 & 0 & 24 & 0 \\
\hline \multicolumn{5}{|c|}{ Golongan betalaktam dan betalactamase inhibitor } \\
\hline Amoksilin/Asam klavulanat & 1 & 4 & 19 & 0 \\
\hline Ampisilin Sulbaktam & 5 & 0 & 19 & 0 \\
\hline Piperasilin tazobaktam & 2 & 3 & 19 & 0 \\
\hline Cefoperazon sulbaktam & 4 & 0 & 20 & 0 \\
\hline Tigesiklin & 3 & 2 & 18 & 1 \\
\hline \multicolumn{5}{|l|}{ Golongan carbapenem } \\
\hline Doripenem & 4 & 1 & 18 & 1 \\
\hline Ertapenem & 2 & 0 & 18 & 4 \\
\hline Meropenem & 5 & 0 & 19 & 0 \\
\hline Imipenem & 5 & 1 & 17 & 1 \\
\hline \multicolumn{5}{|l|}{ Golongan quinolon } \\
\hline Ciprofloksasin & 4 & 1 & 19 & 0 \\
\hline Levofloksasin & 5 & 0 & 18 & 1 \\
\hline Gatifloksasin & 4 & 0 & 17 & 3 \\
\hline Moxifloksasin & 5 & 0 & 18 & 1 \\
\hline \multicolumn{5}{|l|}{ Golongan polimiksin } \\
\hline Kolistin & 3 & 0 & 0 & 21 \\
\hline
\end{tabular}

$\mathrm{R}=$ resisten; I=intermediet; $\mathrm{S}=$ sensitif; $\mathrm{NA}=$ not available

Acinetobacter baumannii menunjukkan adanya resistensi terhadap antibiotik yang diujikan, seperti tertera dalam Gambar 1 dan Tabel 3. Resistensi Acinetobacter baumannii didapatkan pada golongan aminoglikosida, carbapenem, quinolon, sefalosporin, penisilin-beta lactamase inhibitor dan tigesiklin. Data sensitifitas terhadap kolistin hanya tiga pasien, walaupun semuanya sensitif, tetapi masih ada 29 pasien tidak dilakukan uji kepekaan.

\section{Pembahasan}

Sebagai kuman patogen rumah sakit, Acinetobacter baumannii menyerang pasien yang dirawat di ruang rawat intensif, seperti pasien luka bakar, pasien trauma, dan pasien yang menggunakan ventilator mekanik. Pasien immunocompromise juga berisiko untuk menderita infeksi dari kuman ini. Gambaran klinis yang ditimbulkan sangat bervariasi, antara lain hospital acquired pneumonia, ventilator associated pneumonia, infeksi kulit dan jaringan lunak, meningitis, infeksi saluran kemih, infeksi aliran darah, endokarditis, abses intraabdominal, dan infeksi luka operasi. ${ }^{5,11}$ Pada penelitian ini, infeksi Acinetobacter baumannii ditegakkan dari gejala klinis dan pemeriksaan laboratorium yang dipastikan dengan hasil biakan darah positif mengandung bakteri ini.

Semua pasien yang mengalami infeksi Acinetobacter baumannii merupakan pasien yang dirawat di ruang NICU dan tidak ditemukan pasien di bangsal perawatan biasa. Beberapa penelitian sebelumnya melaporkan 
kejadian infeksi Acinetobacter baumannii banyak dijumpai di ruang rawat intensif yang merupakan salah satu faktor risiko terjadinya infeksi Acinetobacter baumannii ini. ${ }^{3}$ Kanokorn $\mathrm{dkk}^{5}$ melaporkan pasien yang mengalami infeksi Acinetobacter baumannii 46\% dirawat di ruang PICU dan $11,9 \%$ di ruang NICU. Sheng dkk ${ }^{12}$ melaporkan 50,4\% pasien yang terinfeksi Acinetobacter baumannii dirawat di ruang rawat intensif.

Acinetobacter baumannii dalam tubuh manusia bisa merupakan koloni saja, dapat dijumpai pada kulit, urin, tinja, dan saluran napas. ${ }^{13}$ Penting untuk membedakan apakah adanya Acinetobacter baumannii merupakan infeksi atau hanya merupakan koloni saja. Selain ada atau tidaknya gejala klinis infeksi, faktor asal bahan isolat juga menentukan apakah ini hanya merupakan koloni atau infeksi. Bahan isolat yang positif mengandung Acinetobacter baumannii berasal dari darah pasien mengindikasikan pasien terinfeksi bakteri ini.

Lama rawat di rumah sakit merupakan salah satu faktor risiko terjadinya infeksi Acinetobacter baumannii. ${ }^{3}$ Rerata lama rawat pada penelitian ini di dapatkan 23,9 hari. Jika dibedakan antara yang MDR dan bukan MDR maka didapatkan lama rawat pada kasus MDR adalah 23,9 hari dan pada kasus bukan MDR 2 hari. Hasil ini hampir sama dengan penelitian yang dilakukan sebelumnya. Penelitian Anunnatsiri $\mathrm{dkk}^{14}$ mendapatkan lama rawat kasus dengan infeksi Acinetobacter baumannii MDR adalah 15,5 hari dan jika dibandingkan dengan kasus yang masih sensitif antibiotik maka didapatkan rasio odds 10,01 (IK95\% 1,39-72,0). Sheng $\mathrm{dkk}^{12}$ mendapatkan lama rawat pasien lebih lama pada kasus Acinetobacter baumannii yang resisten terhadap carbapenem dibandingkan kasus yang sensitif carbapenem (48 dengan 21 hari, $\mathrm{p}<0,0001$ ).

Multidrug resistant merupakan kondisi emergensi dalam penanganan infeksi Acinetobacter baumannii. Insidennya yang terus meningkat merupakan tantangan yang harus diatasi dalam upaya meningkatkan keberhasilan penanganan infeksi bakteri ini. ${ }^{2}$ Anunnatsiri dkk ${ }^{14}$ mendapatkan insiden Acinetobacter baumannii yang MDR adalah 3,6 episode per 10000 episode masuk rumah sakit. Sengstock dkk, ${ }^{15}$ pada tahun 2003-2008, melaporkan terjadi peningkatan insiden panresisten Acinetobacter baumannii sebesar 13,6\%. Balkhy $\mathrm{dkk}^{6}$ menemukan 68 pasien yang terinfeksi Acinetobacter baumannii, 23 (33,8\%) pasien merupakan HAIs dengan kasus MDR. Abbo $\mathrm{dkk}^{16}$ melakukan penelitian antara Januari-Juni 2001 menemukan 133 pasien terinfeksi Acinetobacter baumannii dengan MDR. Penelitian ini mendapatkan dari 24 pasien infeksi Acinetobacter baumannii, 23 kasus merupakan kasus dengan MDR.

Insiden resistensi Acinetobacter baumannii terhadap golongan carbapenem dilaporkan telah terjadi peningkatan. Hong $\mathrm{dkk}^{8}$ mendapatkan 20 pasien dengan infeksi Acinetobacter baumannii yang resisten terhadap imipenem. Seng dkk ${ }^{12}$ melaporkan dari 248 pasien terinfeksi Acinetobacter baumannii, terdapat 121 pasien dengan Acinetobacter baumannii resisten golongan carbapenem. Penelitian ini mendapatkan sebagian besar Acinetobacter baumannii resisten terhadap golongan carbapenem seperti doripenem, ertapenem, meropenem, dan imipenem.

Saat ini, polimiksin B dan kolistin (polimiksin E) merupakan pilihan terapi untuk infeksi Acinetobacter baumannii dengan MDR. Polimiksin B dan kolistin aktif untuk melawan infeksi bakteri Gram negatif seperti Pseudomonas aeruginosa, Klebsiella pneumoniae, dan Acinetobacter baumannii. ${ }^{1,2,11,17-19}$ Aktifitas antimikroba polimiksin B dan kolistin adalah identik, tetapi penggunaan kolistin lebih sering karena faktor pengalaman klinis yang lebih banyak. ${ }^{17}$ Kanokorn $\mathrm{dkk}^{5}$ dalam penelitiannya terhadap pasien anak yang menderita infeksi Acinetobacter baumannii menemukan 96,4\% masih sensitif terhadap kolistin. Paksu $\mathrm{dkk}^{20}$ melaporkan bahwa kolistin masih efektif dalam penanganan infeksi Acinetobacter baumannii yang MDR dan masih dapat di toleransi oleh tubuh dengan baik. Pada penelitian ini didapatkan kolistin masih sensitif terhadap infeksi Acinetobacter baumannii, tetapi sayang, uji kepekaan hanya dilakukan terhadap 3 isolat saja, masih ada 21 isolat yang tidak diuji sehingga tidak diketahui bagaimana pola sensitifitas kuman tersebut terhadap kolistin. Adanya laporan resistensi terhadap kolistin hampir dari seluruh negara di dunia, mulai dari Asia kemudian disusul oleh Eropa, ${ }^{18}$ mengharuskan kita waspada akan terjadinya hal serupa sehingga untuk selanjutnya perlu dilakukan uji kepekaan kolistin atau polimiksin B terhadap setiap isolat yang mengandung Acinetobacter baumannii.

\section{Kesimpulan}

Semua pasien yang menderita infeksi Acinetobacter baumannii dirawat di ruang NICU, sebagian besar pasien merupakan kasus MDR. Resistensi terhadap antibiotik didapatkan pada golongan aminoglikosida, 
golongan carbapenem, golongan quinolon, golongan sefalosporin, golongan penisilin, dan beta lactamase inhibitor dan tigesiklin. Pilihan terapi untuk kasus Acinetobacter baumannii dengan MDR adalah polimiksin B atau kolistin. Uji kepekaan terhadap kedua antibiotik tersebut perlu dilakukan pada setiap isolat yang mengandung Acinetobacter baumannii.

\section{Daftar pustaka}

1. Maragakis LL, Perl TM. Acinetobacter baumannii: epidemiology, antimicrobial resistance, and treatment options. Clin Infect Dis 2008;46:1254-63.

2. Peleg AY, Seifert H, Paterson DL. Acinetobacter baumannii: emergence of a successful pathogen. Clin Microbiol Rev 2008;21:538-82.

3. Fishbain J, Peleg AY. Treatment of Acinetobacter infections. Clin Infect Dis 2010;51:79-84.

4. Hosoglu S, Hascuhadar M, Yasar E, Uslu S, Aldudak B. Control of an Acientobacter baumannii outbreak in a neonatal ICU without suspension of service: a devastating outbreak in Diyarbakir, Turkey. Infection 2012;40:11-8.

5. Kanokorn L, Peninnah O. Acinetobacter baumannii infection and colonization among pediatric patients at Chiang Mai university hospital. Infect Dis Antimicrob Agents 2007;24:63-73.

6. Balkhy HH, Bawazeer MS, Kattan RF, Tamim HM, Johani SM, Aldughashem FA, dkk. Epidemiology of Acinetobacter spp.-associated healthcare infections and colonization among children at a tertiary-care hospital in Saud Arabia: a 6-year retrospective cohort study. Eur J Clin Microbiol Infect Dis 2012;31:2645-51.

7. Corbella X, Montero A, Pujol M, Domínguez A, Ayats J, Argerich MJ. Emergence and rapid spread of carbapenem resistance during a large and sustained hospital outbreak of multiresistant Acinetobacter baumannii. J Clin Microbiol 2000;38:4086-95.

8. Hong KB, Oh HS, Song JS, Lim JH, Kang DK, Son IS, dkk. Investigation and control of an outbreak of imipenem-resistant Acinetobacter baumannii infection in a pediatric intensive care unit. Pediatr Infect Dis J 2012;31: 685-90.

9. Blot S, Vandewoude K, Colardyn F. Nosocomial bacteremia involving Acinetobacter baumannii in critically ill patients: a matched cohort study. Intensive Care Med 2003;29:471-5.

10. Magiorakos AP, Srinivasan A, Carey RB, Carmeli Y,
Falagas ME, Giske CG, dkk. Multidrug-resistant, extensively drug-resistant and pandrug-resistant bacteria: an international expert proposal for interim standard definitions for acquired resistance. Clin Microbiol Infect 2012;18:268-81.

11. Gupta S, Govil D, Kakar PN, Prakash O, Arora D, Das $S$ dkk. Colistin and polymyxin B: a re-emergence. Indian J Crit Care Med 2009; 13:49-53.

12. Sheng WH, Liao CH, Lauderdale TL, Ko WC, Chen YS, Liu JW, dkk. A multicenter study of risk factors and outcome of hospitalized patients with infections due to carbapenem-resistant Acinetobacter baumannii. Int J Infect Dis 2010;14:e764-9.

13. Seifert H, Dijkshoorn L, Gerner-Smidt P, Pelzer N, Tjernberg I, Vaneechoutte M. Distribution of Acinetobacter species on human skin: comparison of phenotypic and genotypic identification methods. J Clin Microbiol 1997;35:2819-25.

14. Anunnatsiri S, Tonsawan P. Risk factors and clinical outcomes of multidrug-resistant Acinetobacter baumannii bacteremia at a University Hospital in Thailand. Southeast Asian J Trop Med Public Health 2011;42:693-703.

15. Sengstock DM, Thyagarajan R, Apalara J, Mira A,Chopra T, Kaye KS. Multidrug- resistant Acinetobacter baumannii: an emerging pathogen among older adults in community hospitals and nursing homes. Clin Infect Dis 2010;50:1611-6.

16. Abbo A,Venezia SN, Hammer-Muntz O, Krichali T, Siegman-Igra Y, Carmeli Y. Multidrug-resistant Acinetobacter baumannii. Emerg Infect Dis 2005;11:229.

17. Zavascki AP, Goldani LZ, Li J, Nation RL. Polymyxin $B$ for the treatment of multidrug resistant pathogens: a critical review. J Antimicrob Chemother 2007;60:120615.

18. Cai Y, Chai D, Wang R, Liang B, Bai N. Kolistin resistance of Acinetobacter baumannii: clinical report, machanism and antimicrobial strategies. J Antimicrob Chemother 2012;67:1607-15.

19. Scott P, Deye G, Srinivasan A, Murray C, Moran K, Hulten E, dkk. An outbreak of multidrug-resistant Acinetobacter baumannii-calcoaceticus complex infection in the US Military health care system associated with military operations in Iraq. Clin Infect Dis 2007;44:1577-84.

20. Paksu MS, Paksu S, Karadag A, Sensoy G, Asilioglu N, Yildizdase D, dkk. Old agent, new experience: colistin use in the paediatric intensive care unit - a multicentre study. Int J Antimicrob Agents 2012;40:140- 4. 